\title{
Performance Evaluation and Simulation of Solar Panel, Wind Mill, Fuel Cell Hybrid System for Small Scale Energy Harvesting
}

\author{
Puneet Kumar Saini, Agnimitra Biswas, and Dipankar Bhanja
}

\begin{abstract}
With depleting conventional energy resources, whole world is now looking for alternatives to meet energy demands. One of the solutions is renewable energy which is non-exhaustible and non-polluting, but problem is intermittent nature of these energies. Hybrid models have been an effective means of generating electricity throughout the world. Lots of research work has been done and continuing to accommodate new advances in this system. This paper focuses on a hybrid system comprising of wind mill, solar photovoltaic (PV) modules, electrolyzers and fuel cell for satisfying small electrical loads in milliwatts .Dynamic analysis of individual components, combination of different components is performed under various load conditions. Characteristic curves of each system are recorded and analysed using clean energy trainer apparatus and software. Comparison is made between solar-wind and solar-wind-fuel cell systems for a given load profile in milliwatt scale. This hybrid system can be used in remote sensing, medical application, electronic gadgets, that consumes milliwatts of energy.
\end{abstract}

Index Terms-Electrolyzers, fuel cell, hybrid system, solar photovoltaic, wind mill.

\section{INTRODUCTION}

What we need today is engineering for sustainability. Need for environmentally benign energy sources cannot be diminished .Our world has been powered from carbon fuel, for more than two centuries, but now we have compelling reasons to believe that this traditional system will likely be supplemented and ultimately replaced with cleaner, smaller plants located near the loads. Creating balance between supply and ever increasing demand of energy poses a big challenge for technocrats, engineers, scientists. The improved quality of life is elevating the world's energy consumption year after year. Among the alternatives, wind and solar energy technologies have drawn a significant attention recently. However, there is a main common drawback of the solar and wind energy technologies: the dependence on climatic conditions. This dependence lowers the reliability of these sources for ensuring the energy demand/production balance at each instant as the power production of wind turbines and photovoltaic units directly changes with the variation of wind speed, solar irradiation and temperature in the constructed area. Thus, a back-up as well as an energy storage unit is an indispensable requisite for

Manuscript received June 23, 2014; revised September 28, 2014

P. K. Saini is with the Mechanical Engineering Department, RIMT Institutes, Punjab, India (e-mail: sainipuneet497@gmail.com).

A. Biswas and D. Bhanja are with the Mechanical Engineering Department, National Institute of Technology, Silchar, India (e-mail: agnibis@mec.nits.ac.in, dipankar@mec.nits.ac.in). the reliable operation of such technologies [1]. A system composed of such alternative energy technologies and back-up as well as energy storage units is called a "hybrid alternative energy system". A lot of research work has been done for macro-scale energy harvesting technologies using different hybrid systems at large scale (kilowatts, megawatts) [2]-[12], but there have been very few attempts on the development of small scale energy harvesting, those that are miniature in size and highly portable and has application in different fields, for example to power an autonomous sensor deployed in remote location for sensing. Now, as designers seek to cut the cords, they turn to small scale energy harvesting systems that can scavenge milliwatts from solar, wind, Thermal, and Hydrogen sources. Although very few research works are reported in literature for small scale energy harvesting, some effort to harvest small scale energy have been made recently. Park et al. [13], Holmes et al. [14] and Weimer $e t a l$. [15] use small wind mill to generate energy. Priya et al. [16], Myers et al. [17] designed a wind mill that uses piezoelectric elements to generate electricity but no research work had been published yet for small scale energy harvesting using a hybrid system of solar, wind, electrolysers and fuel cells. This paper reports performance assessment of different combinations of solar, wind, electrolyser and fuel cell systems under different load condition with different parameters using table-top model. A comparative study is also performed for hybrid system with and without fuel cell for a given load profile (in milliwatts).

\section{HYBRID POWER SYSTEM}

\section{A. Solar Photovoltaic Module}

Solar (PV) module serves for the generation of electric energy from solar energy. The solar cell is the basic building of the PV power system. Solar array or panel is a group of a several modules electrically connected in series, parallel combination to generate the required current and voltage. The conversion process of sunlight into electricity is known as the photovoltaic effect. The electrical characteristics of the PV module are generally represented by the current vs. voltage $(\mathrm{I}-\mathrm{V})$ and the Power vs. voltage (P-V) curves. Properties of single solar (PV) module are provided in Table I.

TABLE I: TECHNICAL SPECIFICATIONS OF SingLE SOLAR MODULE

\begin{tabular}{|l|l|}
\hline Designation & Specification \\
\hline Power & $2.0 \mathrm{~V} / 600 \mathrm{~mA}$ \\
\hline Dimensions $W \times H \times D$ & $95 \times 135 \times 30 \mathrm{~mm}$ \\
\hline Weight & $89 \mathrm{~g}$ \\
\hline
\end{tabular}


$I-V$ characteristic of the PV module are:

$$
I=I_{1}-I_{O}\left(e^{q(V+I R s) / n k T}-1\right)
$$

where $I_{1}=$ photo current; $I_{o}=$ diode saturation current; $R s=$ series current; $q=$ charge of electron; $k=$ constant; $T=$ temperature and $N=$ number of PV module.

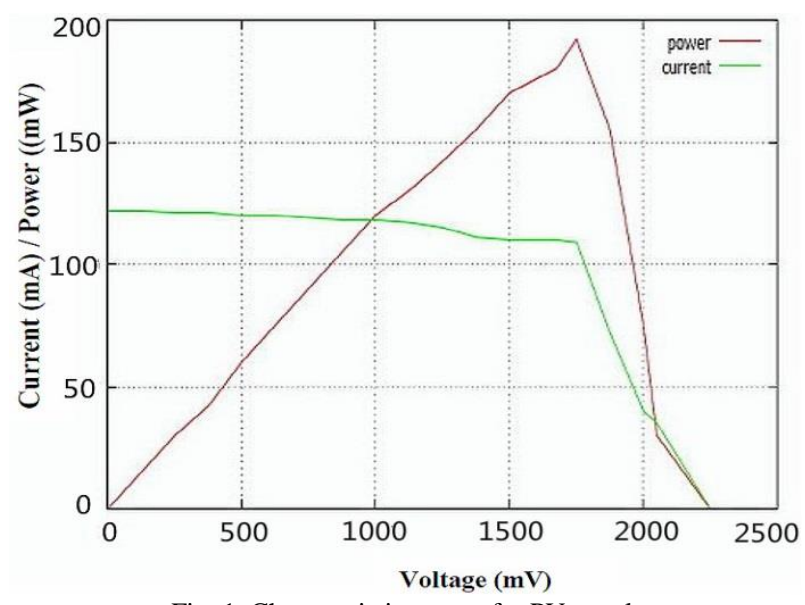

Fig. 1. Characteristics curve for PV panel.

Fig. 1 shows $I-V$ and $P-V$ characteristic of single solar module with one lamp and angle of irradiance 90 degrees. Solar module provide maximum power approximately $1.7 \mathrm{~V}$ and $120 \mathrm{~mA}$ (with one $75 \mathrm{~W}$ lamp).

\section{B. Wind Turbine}

Wind energy is the fastest growing renewable energy sector. Problem is that only selected locations have wind resources that are sufficiently strong and steady to be attractive for exploitation. Utilization of hydrogen to produce electricity is controllable and can fulfil the grid demands when electricity from wind cannot be generated. Wind energy has large seasonal variations for generation. Variation of wind energy is not limited to short period, but they also significantly fluctuate within seasons and years, therefore robust strategies for on-line operations of electrolysers and fuel cell must be applied in order to obtain continuous output.

Wind generator adopted in this paper is horizontal axis turbine with 6 blades which is coupled to permanent magnet synchronous generator whose output is provided to interface (USB data monitor) which in turn is connected to computer.Wind turbine used has specification as given in Table II.

TABLE II: TECHNICAL SPECIFICATIONS OF WIND TURBINE

\begin{tabular}{|l|l|}
\hline Designation & Specification \\
\hline Power & $P_{\text {max. }} 1.2 \mathrm{~W}$ \\
\hline Voltage & $U_{\max .} 3.5 \mathrm{~V}$ \\
\hline Current & $I_{\max .} 149 \mathrm{~mA}$ \\
\hline
\end{tabular}

Blades of wind mill can be freely adjusted to find suitable angle for maximum power output, number of blades can also change. The angle of inclination has significant influence on power of wind generator. If rotor blades are not aligned favorably rotor may not rotate. Wind characteristic curve is shown in Fig. 2 with no flow disruption. Flow disruption will drop values of voltage and current considerably. Fig. 2 show power, $I-V$ characteristics for maximum no of blades (6) and optimum angle of twist with fixed wind velocity.

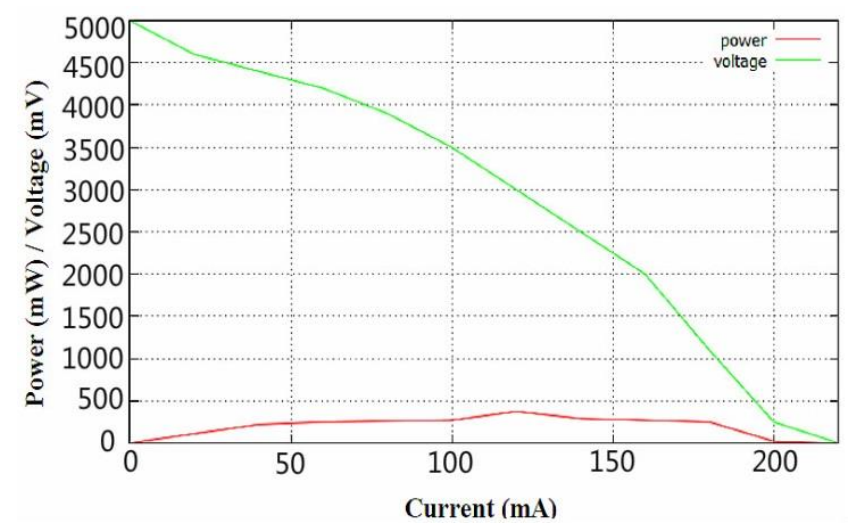

Fig. 2. Characteristics curve of wind turbine.

The mechanical power obtained from wind turbine rotor shaft $\left(P_{\text {wind }}\right)$ is given by:

$$
P_{\text {wind }}=\frac{1}{2} A_{r} \rho C_{p} V_{w}^{3}
$$

where $A r=$ area covered by rotor blades $\left(\pi r^{2}\right)$,

$C_{p}=$ performance coefficient (or power coefficient)

$\rho=$ air density $\left(\mathrm{kg} / \mathrm{m}^{3}\right)$

The theoretical maximum value of the power coefficient $C_{p}$ is 0.59 and it is often expressed as function of the rotor tip speed to wind-speed ratio (TSR), which is defined as:

$$
\mathrm{TSR}=\frac{\text { Blade Tip speed }}{\text { Wind speed }}=\frac{\omega \cdot R}{V_{w}},
$$

where $R$ and $\omega$ are the turbine radius and the angular speed respectively. Whatever maximum value is attainable with a given wind turbine, it must be maintained constant at that value for the efficient capture of maximum wind power. Power is directly proportional to wind speed, as the wind speed increases the power delivered by a wind turbine also increases.

\section{Electrolyzer}

When DC current is passed through electrodes immersed in water, hydrogen and oxygen is generated through electrolysis process. Electrolyzer is a device which uses this principle to generate hydrogen. An electrolyte which can be solid, liquid is decomposed during electrolysis through the application of electric voltage. In this process, hydrogen, noble metals are separated at cathode and Oxygen is separated at anode. Following reaction takes place during electrolysis of water

$$
\mathrm{H}_{2} \mathrm{O}+\text { electricenergy } \rightarrow \mathrm{H}_{2}+\frac{1}{2} \mathrm{O}_{2}
$$

Rate of hydrogen production in electrolyzer is directly proportional to electrolyzing current across the circuit (faraday's law). Hydrogen is generated from electrolyzer which is stored as an energy source. Two electrolyzers are adopted for experimentation, with 4 storage canisters. Storage canisters are used to store hydrogen and oxygen. 
TABLE III: TECHNICAL SPECIFICATIONS IF ELECTROLYZERS

\begin{tabular}{|l|l|}
\hline Designation & Specification \\
\hline Hydrogen production & $5 \mathrm{~cm}^{3} / \mathrm{min}$ \\
\hline Oxygen production & $2.5 \mathrm{~cm}^{3} / \mathrm{min}$ \\
\hline Power & $1.16 \mathrm{~W}$ \\
\hline Max. Permissible voltage & $2.0 \mathrm{~V}$ \\
\hline $\mathrm{H} \times \mathrm{W} \times \mathrm{D}$ & $50 \times 40 \times 57 \mathrm{~mm}$ \\
\hline Weight & $54 \mathrm{~g}$ \\
\hline
\end{tabular}

Technical specifications of one electrolyzer are given in Table III. Voltage at which water begin to decompose is called decomposition voltage. Theoretically its value is 1.23 $\mathrm{V}$, but practically at $1.5 \mathrm{~V}$, a clear formation of gas can be observed. Difference between theoretical and practical value is called overvoltage. Overvoltage can be understood as kinetic inhibition, in other words the braking of reaction.

\section{Fuel Cell}

Fuel cell is a device whose basic function is conversion of chemical energy which is present in hydrogen and oxygen into electrical energy. Types of fuel cell include alkaline fuel cell, PEM fuel cell, direct methanol fuel cell, solid oxide fuel cell, molten carbonate fuel cell and phosphoric acid fuel cell. PEM (proton exchange membrane) fuel cell is used for this study, which compromise of polymer membrane which is provided with a catalytical coating on both side and spatially separated from the gasses hydrogen and oxygen. Gas flow plates lies on outer side of electrode. The gas flow plates have channels through which hydrogen and oxygen flow in order to come in contact with entire surface of electrodes.

Fuel cell stack used for this study has 5 cells; number of cells can also vary. Technical specification for fuel cell is as given in Table IV.

TABLE IV: TECHNICAL SPECIFICATIONS OF FUEL CELL
\begin{tabular}{|l|l|}
\hline Designation & Specification \\
\hline Max. Power & $1 \mathrm{~W}$ \\
\hline Power & $200 \mathrm{~mW}$ per cell \\
\hline Generated voltage & $96 \mathrm{~V}$ per cell \\
\hline $\mathrm{H} \times \mathrm{W} \times \mathrm{D}$ & $60 \times 70 \times 175 \mathrm{~mm}$ \\
\hline Weight & $430 \mathrm{~g}$ \\
\hline
\end{tabular}

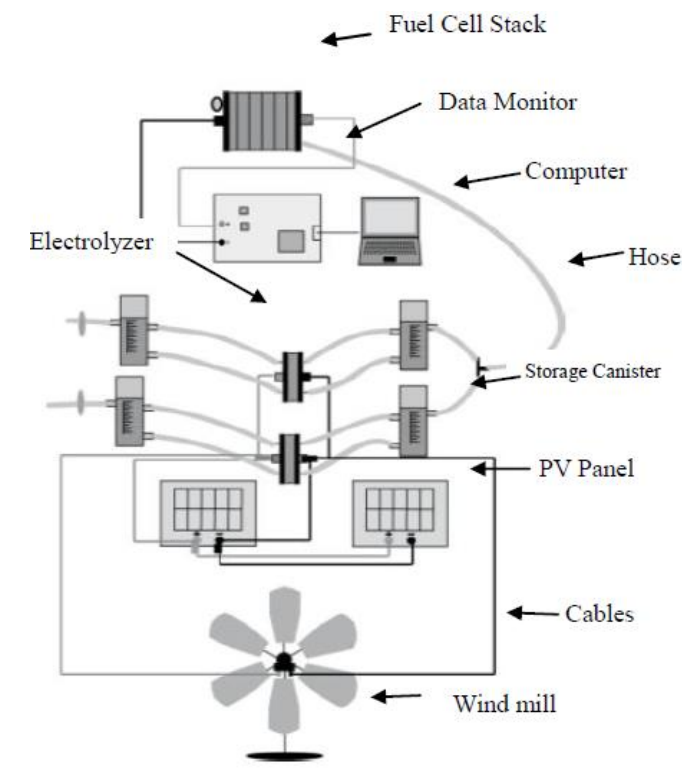

Fig. 3. System configuration of proposed hybrid system.

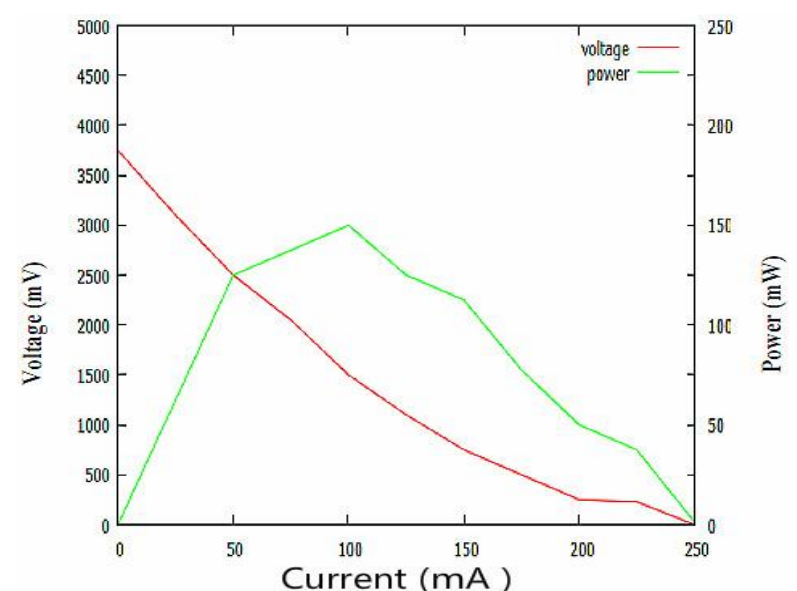

Fig. 4. Charactersticts curve of hybrid system.

Hybrid system configuration used for experimentation is shown in Fig. 3 in which Output from 2 solar panels and wind turbine is given to electrolyzers. Wind turbine is allowed to rotate using wind simulator. When lamps will be $\mathrm{ON}$, radiation will fall on solar panels, and voltage will generated, which will act as input for electrolyzers. When voltage from solar panel, wind turbine will reach near $1500 \mathrm{mV}$, hydrogen will start generating in electrolyzers and will be stored in storage canisters. Hydrogen from these canisters flows to fuel cell stack, which is connected to USB data monitor and computer. Output from hybrid system is recorded and is shown in Fig. 4 in which voltage drops from $3.7 \mathrm{~V}$ to zero as current increases. Maximum power is $3 \mathrm{~V}$ at $105 \mathrm{~mA}$ which is more than that of a single solar panel and wind mill.

\section{LOAD PROFILE SIMULATION}

Different load profile are selected and simulated in software using hybrid system. Various consumers with different utilization over the course of the day is represented with these load profiles. Two usage levels are selected based upon set of home appliances. $\mathrm{x}$ axis represent time and $\mathrm{y}$ axis represent current (mA). First level is low load/part load conditions with peak current of $160 \mathrm{~mA}$. Simulation with low load is shown in Fig. 5. Different combinations ( 1 solar panel -wind mill, 2 solar panels in series -wind mill, 2 solar panel in parallel - wind mill, 2 solar panels- wind mill-electrolyzers- fuel cell ) are simulated at this level and results obtained is shown in Fig. 5, which show above listed system are able to meet low load demand. Second selected level is high/peak load with peak current at $740 \mathrm{~mA}$. Simulation for this level is shown in Fig. 6.

Results show that only (solar panel-wind mill-electrolyzers -fuel cell) system is able to satisfy high load demands. The goal of simulation is to predict behavior of hybrid system with varying load.

A comparison is made between hybrid system without fuel cell and with fuel cell for a given load profile. Fig. 7 shows simulation for hybrid system at high load when there is no fuel cell. It can be easily seen from curve that system is not able to satisfy load demands .Maximum current provided by system is $450 \mathrm{~mA}$ while requirement is $660 \mathrm{~mA}$. But if fuel cell is incorporated in the system, then load requirement are fully satisfied as clear from Fig. 6, so wind, solar, fuel cell system gives better response under varying load conditions. 


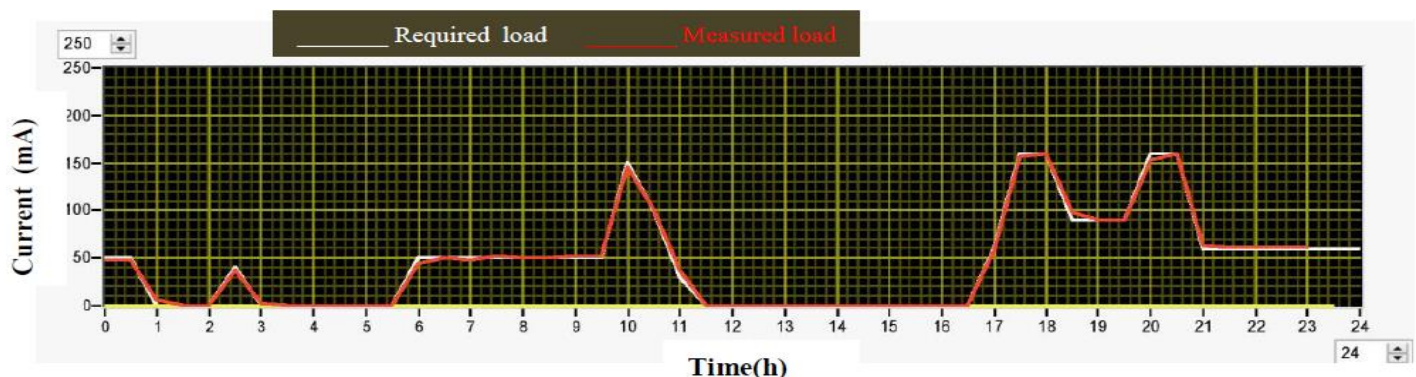

Fig. 5. Simulation of hybrid system at low load.

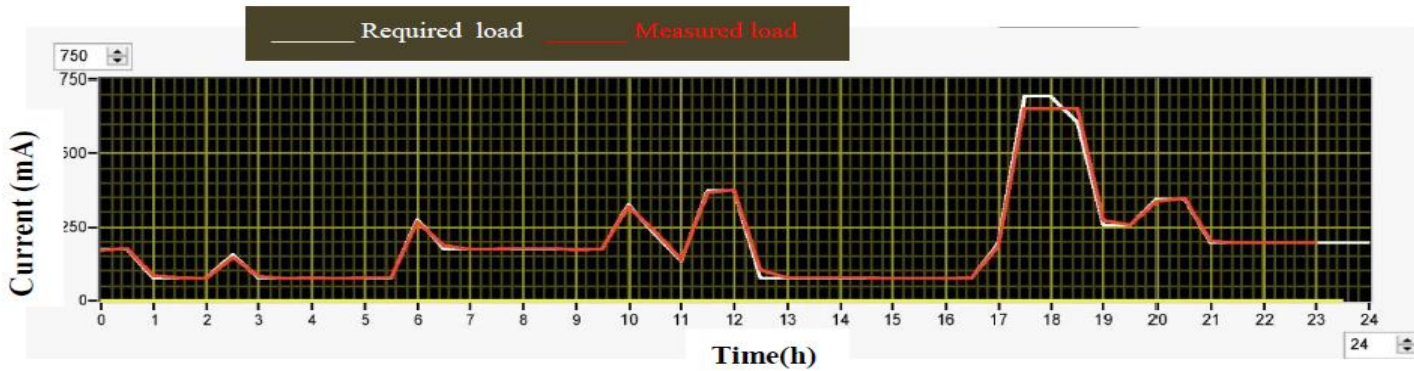

Fig. 6. Simulation of hybrid system with fuel cell at high load.

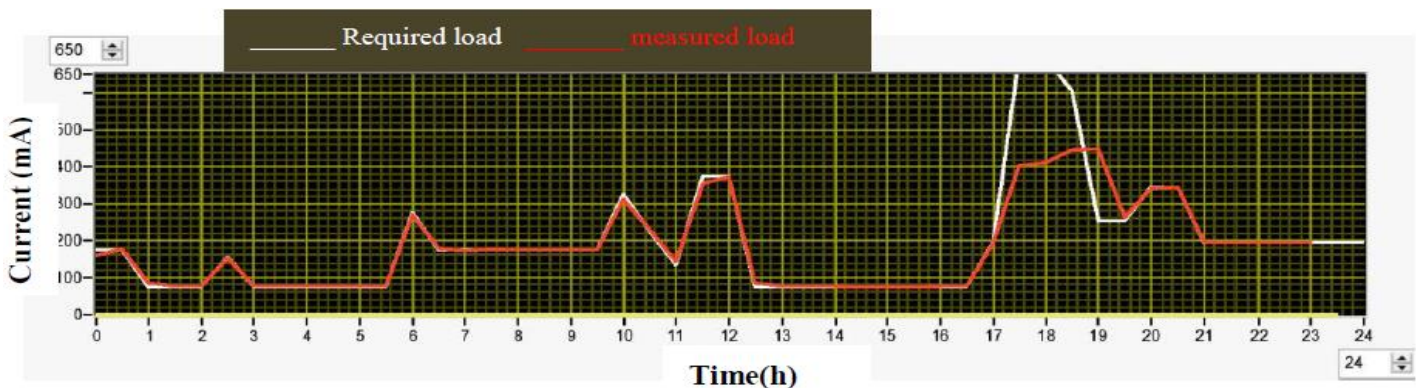

Fig. 7. Simulation without fuel cell at high load.

\section{CONCLUSIONS}

Macro-scale harvesting technologies generally add kilowatts or megawatts to the power distribution system. Energy harvesting's new frontier is an array of micro-scale technologies that scavenge milliwatts from solar, wind, electrolyzer and fuel cell sources. Therefore, this paper presents a solar PV, wind turbine and fuel cell hybrid generation system to obtain continuity in output at small loads in milliwatt scale. A simulation model of hybrid system is developed which describe its operation with varying load depends on utilization of consumers. Results show that many systems satisfy low load demands but only one system compromising of solar-wind-electrolyser-fuel cell is able to meet high load demand. A comparative study is also performed which prove fuel cell a better energy source under high loads. The most promising application of this technology is remote sensing, low power electronic devices like mobile gadget, medical applications (medical implants, ear devices, surface-of-skin device), non-medical products e.g calculators, watches, radios, that consumes milliwatts of energy.

\section{REFERENCES}

[1] K. Sapru, N. T. Stetson, and S. R. Ovshinsky, "Development of a small scale hydrogen production storage system for hydrogen applications," in Proc. the 32nd Intersociety Conference, vol. 3, pp. 1947-1952.

[2] S. R. Vosen and J. O. Keller, "Hybrid energy storage systems for stand-alone electric power systems: Optimization of system performance and cost through control strategies," International
Journal of Hydrogen Energy, vol. 24, no. 12, pp. 1139-1156, Dec. 1999.

[3] D. B. Nelson, M. H. Nehrir, and C. Wang, "Unit sizing and cost analysis of stand-alone hybrid Wind/PV/fuel cell systems," Renewable Energy, vol. 31, no. 10, pp. 1641-1656, Aug. 2006.

[4] C. Wang, "Modeling and control of hybrid wind/photovoltaic/fuel cell distributed generation systems," Ph.D. dissertation, Montana State Univ., Bozeman, 2006.

[5] M. T. Iqbal, "Modeling and control of a wind fuel cell hybrid energy system," Renewable Energy, vol. 28, no. 2, pp. 223-237, Feb. 2003.

[6] T. F. El-Shatter, M. N. Eskandar, and M. T. El-Hagry, "Hybrid PV/fuel cell system design and simulation," Renewable Energy, vol. 27, no. 3, pp. 479-485, Nov. 2002.

[7] R. Chedid, H. Akiki, and S. Rahman, "A decision support technique for the design of hybrid solar-wind power systems," IEEE Trans. Energy Convers., vol. 13, no. 1, pp. 76-83, Mar. 1998.

[8] P. R. Chedid and S. Rahman, "Unit sizing and control of hybrid wind solar power systems," IEEE Transaction of Energy Conversion, vol. 12, no. 1, March 1997.

[9] F. A. Farret and M. G. Simões, Integration of Alternative Sources of Energy, John Wiley \& Sons, Inc., 2006.

[10] C. A. Naci. "Techno-economic analysis of autonomous PV-wind hybrid energy systems using different sizing methods," J. Energy Convers Manage, pp. 1162-1168, 2003.

[11] A. Nabil and M. Masafumi, "A stand-alone hybrid generation system combining solar photovoltaic and wind turbine with simple maximum power point tracking control," in Proc. CES/IEEE $5^{\text {th }}$ International Power Electronics and Motion Control Conference, Shanghai, China, 13-16 August, 2006.

[12] B. Roy and K. Rajesh, "Capacity expansion of small isolated power systems using PV and wind energy," IEEE Trans Power System, vol. 6 , no. 4, pp. 892-897, 2001.

[13] C. Park and P. H. Chou, "AmbiMax: Autonomous energy harvesting platform for multi-supply wireless sensor nodes," in Proc. $3^{\text {rd }}$ Annual IEEE Communications Society on Sensor and Ad Hoc Communications and Networks, 2006, vol. 1, pp. 168-177.

[14] A. S. Holmes, G. Hong, K. R. Pullen, and K. R. Buffard, "Axial-flow microturbine with electromagnetic generator: Design, CFD simulation, 
and prototype Demonstration," in Proc. 17th IEEE International Conference on Micro Electro Mechanical Systems, 2004, pp. 568-571.

[15] M. A. Weimer, T. S. Paing, and R. A. Zane, "Remote area wind energy harvesting for low-power autonomous sensors," in Proc. 37th IEEE Power Electronics Specialists Conference, 2006, pp. 2911-2915.

[16] S. Priya, C. T. Chen, D. Fye, and J. Zahnd, "Piezoelectric windmill: A novel solution to remote sensing," Japanese Journal of Applied Physics, vol. 44, no. 3, pp. L104-L107, 2005.

[17] Myers, M. Vickers, K. Hyeoungwoo, and S. Priya, "Small-scale windmill," Applied Physics Letters, vol. 90, no. 5, pp. 54106-1-3, 2007.

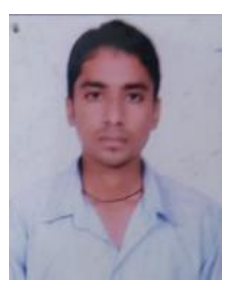

Puneet Kumar Saini is a student pursuing his bachelor degree in mechanical engineering from RIMT Institutes, Mandi Gobindgarh, Punjab, India. His areas of interest include power plant technology, renewable energy resources, and thermal energy storage system.

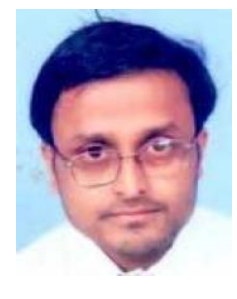

Agnimitra Biswas received his B.E. degree in mechanical engineering from Regional Engineering College Silchar under Assam University in 2001, M.Tech degree in thermal engineering from NIT Silchar in 2007, and $\mathrm{PhD}$ degree in mechanical engineering from NIT Silchar in 2010. He did his research on vertical axis wind turbines using experimental and computational methods. $\mathrm{He}$ is an associate member of Institute of Engineers (India).

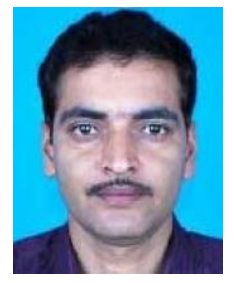

Bhanja obtained his B.E. degree in mechanical engineering from Jalpaiguri Government Engineering College under North Bengal University in 2000. Then he received the M.E. degree in production engineering from Jadavpur University in 2002, and Ph.D. degree in the field of heat transfer from Jadavpur Universtiy, Kolkata in 2014. He has over 12 years of teaching and research experience. He is a reviewer of various reputed international journals. His areas of interest are thermal engineering, heat transfer, production management. 
Bioenergy 
